\title{
TRANSNASAL SPHENOPALATINE GANGLION BLOCK FOR TREATMENT OF POSTDURAL PUNCTURE HEADACHE IN OBSTETRIC PATIENTS
}

M. Viegas Ribeiro', $\underline{\text { J. Pacheco }}^{1}$, F. Lança ${ }^{1}$

${ }^{1}$ Anesthesiology Department, Centro Hospitalar Lisboa Norte, Lisboa, Portugal (Head of Department: Prof. Dr. Lucindo Ormonde)

\section{Background and Aims}

Sphenopalatine ganglion (SPG) is a parasympathetic ganglion, located in the pterygopalatine fossa. It has been used for treating headaches of multiple etiologies. These two cases comprise SPG block used to treat postdural puncture headache (PDPH) in postpartum patients.

\section{Methods}

We performed a transnasal SPG block using a cotton-tipped applicator and 2\% lidocaine. Pain assessment was performed using the numeric rating scale (NRS) and it was made before performing the technique and at $0,2,6,12,24$ and 48 hours after the block.

\section{Results}

Two women, ages 30 and 27, developed PDPH after spinal analgesia using a $27 \mathrm{G}$ and a $25 \mathrm{G}$ Quincke needle, respectively. Before the treatment they described 9/10 and 10/10 pain, and after both of them reported significant pain relief within the first 5 minutes. A high degree of pain relief was sustained throughout the first 24 hours posttreatment, however after this period there was a recurrence of pain, although less intense (8/10). In both patients an epidural blood patch (EBP) was performed after recurrence of pain, which provided symptomatic relief allowing discharge after 24 hours.

\begin{tabular}{|c|c|c|}
\hline $\begin{array}{c}\text { Patient } \\
\text { number }\end{array}$ & $\begin{array}{c}\text { NRs before } \\
\text { procedure in } \\
\text { orthostatism }\end{array}$ & $\begin{array}{c}\text { NRs before } \\
\text { procedure in } \\
\text { supine position }\end{array}$ \\
\hline 1 & 9 & 2 \\
\hline 2 & 10 & 4 \\
\hline
\end{tabular}

Table 1 - Evaluation of pain before sphenopalatine ganglion block

\begin{tabular}{|c|c|c|c|c|c|}
\hline $\begin{array}{c}\text { Patient } \\
\text { number }\end{array}$ & $\begin{array}{c}\text { NRs } \\
\text { (0 hours) }\end{array}$ & $\begin{array}{c}\text { NRs } \\
\text { (2 hours) }\end{array}$ & $\begin{array}{c}\text { NRs } \\
(6 \text { hours })\end{array}$ & $\begin{array}{c}\text { NRs } \\
(12 \text { hours })\end{array}$ & $\begin{array}{c}\text { NRs } \\
\text { (24 hours })\end{array}$ \\
\hline 1 & 0 & 0 & 0 & 0 & 8 \\
\hline 2 & 2 & 1 & 0 & 3 & 8 \\
\hline
\end{tabular}

Table 2 - Evaluation of pain after sphenopalatine ganglion block

\section{Conclusions}

Transnasal SPG block is a safe and easy technique with fewer complications than EBP. In both cases adequate analgesic control has been achieved, but its effect was limited in time. PDPH is a self-limited complication with spontaneous resolution in most cases. The SPG block can be reapeated until the resolution of the condition, avoiding more invasive techniques with higher risk of severe complications such as the EBP.

\section{References}

1. Cohen S, Sakr A, Katyal S, Chopra D. Sphenopalatine ganglion block for postdural puncture headache. Anaesthesia 2009; $64: 574-5$

2. Kent S, Mehaffey G. Transnasal sphenopalatine ganglion block for the treatment of postdural puncture headache in obstetric patients. J Clin

Anesth 2016; 34: 194-6 